\title{
Karakteristik Psikologis Atlet PON Bengkulu Ditinjau dari Cabang Olahraga Individu
}

\section{Psychological Characteristics Of PON Bengkulu Athletes In Terms Of Individual Sports}

\author{
Anggit Triananda $^{1}$, Syafrial $^{2}$, Yahya Eko Nopiyanto ${ }^{3}$ \\ ${ }^{123}$ Pendidikan Jasmani, Universitas Bengkulu,Jl WR Supratman, Bengkulu, 38113, Indonesia
}

\begin{abstract}
Abstrak
Penelitian ini bertujuan untuk mengungkapkan: (1) karakteristik psikologis atlet PON Bengkulu ditinjau dari cabang olahraga individu, (2) perbedaan karakteristik psikologis antara atlet laki-laki dan perempuan ditinjau dari cabang olahraga individu. Pendekatan penelitian ini adalah kuantitatif menggunakan metode survei dengan desain penelitian $a$ restrospective causal-comparative design. Penelitian ini merupakan penelitian populasi. Semua subjek dalam populasi diikutsertakan dalam penelitian dengan jumlah 42 atlet. Teknik pengumpulan data menggunakan kuesioner The Psychological Skills Inventory for Sports (PSIS). Teknik analisis data menggunakan independent sample t-test dengan taraf signifikansi 0,05. Hasil penelitian ini menunjukkan bahwa: (1) karakteristik psikologis atlet PON Bengkulu ditinjau dari cabang olahraga individu mempunyai nilai rerata 42,9 dalam kategori sedang, (2) terdapat perbedaan yang signifikan terhadap atlet laki-laki dan atlet perempuan dengan nilai rerata 128,22 untuk atlet laki dan 122,68 untuk atlet perempuan. Jadi, dapat disimpulkan bahwa karakteristik ksikologis atlet PON Bengkulu ditinjau dari cabang olahraga individu masuk ke dalam kategori sedang, dan terdapat perbedaan yang signifikan antara karakteristik psikologis atlet laki-laki dan atlet perempuan.
\end{abstract}

Kata kunci: karakteristik, psikologis, atlet pon bengkulu, olahraga individu

\begin{abstract}
This study aims to reveal: (1) the psychological characteristics of PON Bengkulu athletes in terms of individual sports, (2) differences the psychological characteristics between male and female athletes in terms of individual sports. This research approach was quantitative using survey method with research design a restrospective causalcomparative design. All subjects in the population were included in the study with a total of 42 athletes. Data collection techniques using The Psychological Skills Inventory for Sports (PSIS) questionnaire. Data analysis techniques using independent sample t-test with significance level 0.05. The results of this study showed that: (2) the psychological characteristics of PON Bengkulu athletes were reviewed from individual sports in the Medium category with an average score of 42.9, (2) There were significant differences between male athletes and female athletes with a mean score of 128.22 for male athletes and 122.68 for female athletes. So it can be concluded that the psychological characteristics of PON Bengkulu athletes in terms of individual sports were moderate category, and there were significant differences between the psychological characteristics of male and female athletes.
\end{abstract}

Keywords: characteristics, psychological, pon bengkulu athletes, individual sports 



\section{PENDAHULUAN}

Psikologi yaitu studi tentang proses mental atau psikologis. Psikologi olahraga merupakan ilmu yang mempelajari psikologi yang berkaitan dengan kegiatan keolahragaan. Kemajuan atau prestasi olahraga, ialah perkembangan kesehatan atau tubuh, juga akan berdampak terhadap kondisi mental seseorang. Dapat pula ditemukan bahwa kondisi psikologis juga dapat mempengaruhi proses pencapaian kesehatan atau latihan fisik. Kedua hal inilah yang mempengaruhi kesuksesan olahraga.

Keberhasilan atau kegagalan atlet yang mengikuti olahraga berprestasi tergantung pada pengaruh komprehensif faktor fisik, taktis, teknis dan spiritual. Melalui pemaparan tersebut, semangat ialah salah satu faktor penting yang mempengaruhi performa atlet. Pelatih percaya jika tidak kurang dari 50\% kesuksesan ditentukan oleeh faktor psikologis (Weinberg \& Gould, 2011).

Untuk membentuk karakteristik psikologis atlet, para pelatih dapat menerapkan latihan keterampilan psikologis. Karakteristik psikologis atlet adalah ciri psikologis yang akan mempengaruhi keberhasilan atlet dalam olahraga yang terdiri dari motivasi, kepercayaan diri, kontrol kecemasan, pentingnya tim, persiapan mental, dan konsentrasi (Nopiyanto \& Dimyati, 2018). Setiap cabang olahraga memiliki perbedaan yang mendasar pada karakteristik masing-masing psikologi atlet. Perbedaan tersebut bisa dari gerak tubuh, peraturan yang dipakai dan perilaku atlet yang ditimbulkan dari setiap cabang olahraga akan membentuk karakteristik yang berbeda (Herawati, 2014). Sebelum menerapkan latihan keterampilan psikologis maka pelatih harus mengetahui tingkat karakteristik psikologis atlet yang dilatihnya.

Banyak faktor yang mempengaruhi prestasi atlet PON Bengkulu, salah satunya faktor jenis kelamin, dimana setiap atlet pada cabang olahraga tertentu yang lebih spesifik akan memperoleh prestasi yang cemerlang. Salah satunya yaitu penelitian yang pernah dilaksanakan oleh Nopiyanto dan Alimuddin (2020), yang mengkaji tentang karakteristik psikologis atlet Sea Games Indonesia ditinjau dari jenis kelamin pada olahraga tim dan diketahui bahwa ada perbedaan yang signifikan antara atlet laki-laki dan atlet perempuan. Namun, hingga saat ini belum ditemukan penelitian yang membahas mengenai karakteristik psikologis 
atlet PON Bengkulu ditinjau dari cabang olahraga individu. Sehingga peneliti tertarik untuk mengkaji lebih lanjut mengenai karakteristik psikologis atlet PON Bengkulu sebagai upaya untuk memperbaiki tingkat karakteristik psikologis atlet.

\section{METODE}

Penelitian ini merupakan jenis penelitian kuantitaif. Metode yang digunakan yaitu causal comperative design (Gay dan Airasian, 2011) yaitu penelitian yang bertujuan untuk mengetahui perbedaan karakteristik psikologis atlet PON Bengkulu ditinjau dari cabang olahraga individu. Penelitian ini mengambil populasi dari atlet yang akan bertanding di PON Papua 2021 yang berjumlah 42 atlet, dan teknik sampling yang digunakan adalah total sampling sehingga sampel yang digunakan yaitu 42 orang atlet. Tempat penelitian ini yaitu di kota Bengkulu pada tanggal 20 Agustus hingga 20 September 2020. Teknik pengumpulan data ini menggunakan kuisioner, yaitu The Psychological skill inventory for sports (PSIS). Teknik analisis data dalam penelitian ini menggunakan bantuan software Statistical Product and Service Solution (SPPS) versi 23.0. Peneliti merumuskan standar berdasarkan nilai rata-rata dan standar deviasi ideal untuk mengetahui karakteristik psikologis atlet PON, kemudian mengelompokkan datanya sesuai rumus berikut :

$$
\begin{gathered}
\mathrm{MI}=\frac{(S T+S R)}{2} \\
\mathrm{SDi}=\frac{(S T-S R)}{6}
\end{gathered}
$$

Keterangan :

Mi : Mean ideal, SDi : Standar deviasi ideal, ST : Skor Tertinggi, SR : Skor Terendah 
Tabel 1. Rumus Penentuan Kriteria

(Sumber: Wagiran, 2015)

\begin{tabular}{lcc}
\hline No & Interval & Kategori \\
1 & $(\mathrm{Mi}+1,9 \mathrm{SD})$ s.d. $(\mathrm{Mi}+3 \mathrm{SD})$ & Sangat tinggi \\
2 & $(\mathrm{Mi}+0,7 \mathrm{SD})$ s.d. $(\mathrm{Mi}+1,8 \mathrm{SD})$ & Tinggi \\
3 & $(\mathrm{Mi}-0,7 \mathrm{SD})$ s.d. $(\mathrm{Mi}+0,6 \mathrm{SD})$ & Sedang \\
4 & $(\mathrm{Mi}-1,9 \mathrm{SD})$ s.d. $(\mathrm{Mi}-0,6 \mathrm{SD})$ & Rendah \\
5 & $(\mathrm{Mi}-3 \mathrm{SD})$ s.d. $(\mathrm{Mi}-1,8 \mathrm{SD})$ & Sangat rendah \\
\hline
\end{tabular}

\section{HASIL}

Penelitian ini dilaksanakan di kota Bengkulu dalam penelitian ini peneliti meneliti 42 orang atlet yang terdaftar sebagai atlet PON yang akan bertanding di PON Papua yang ke-20 yang terdiri dari 13 cabang olahraga yaitu : atletik, renang, bulutangkis, biliar, panjat tebing, tinju, muaythai, selam, angkat besi binaraga dan angkat berat, gulat karate, tenis lapangan dan silat. Karakteristik psikologis atlet PON Bengkulu ditinjau dari cabang olahraga individu secara umum dapat dilihat pada tabel berikut ini:

Tabel 2. Karakteristik Psikologis Atlet PON Bengkulu ditinjau dari cabang olahraga individu secara umum

\begin{tabular}{lllcc}
\hline No & Kategori & Skor & Frekuensi & Persentase \\
1 & Sangat Tinggi & 137,9 s.d 146,3 & 3 & 7,1 \\
2 & Tinggi & 128,4 s.d. 136,8 & 16 & 38,1 \\
3 & Sedang & 118,9 s.d 127,3 & 18 & 42,9 \\
4 & Rendah & 109,4 s.d 117,8 & 4 & 9,5 \\
5 & Sangat Rendah & 100,0 s.d. 108,4 & 1 & 2,4 \\
\hline & & Jumlah & 42 & 100 \\
\hline
\end{tabular}

Dari tabel 2 dapat diketahui bahwa karakteristik psikologis atlet PON Bengkulu ditinjau dari cabang olahraga individu secara umum terdiri dari 3 atlet yang termasuk pada kategori sangat tinggi, 16 atlet termasuk pada kategori tinggi, 18 atlet termasuk pada kategori sedang, 4 atlet termasuk pada kategori rendah, 1 atlet termasuk pada kategori sangat rendah. Apabila dilihat dari persentase dapat 
diketahui bahwa secara umum $7,1 \%$ atlet termasuk pada kategori sangat tinggi, $38,1 \%$ atlet termasuk pada kategori tinggi, 42,9\% termasuk pada kategori sedang, 9,5\% atlet termasuk pada kategori rendah, 2,4\% termasuk pada kategori sangat rendah. Jadi dapat disimpulkan bahwa karakteristik psikologis atlet PON Bengkulu ditinjau dari cabang olahraga individu secara umum berada dikategori sedang. Hasil dari masing- masing kategori dapat dilihat pada gambar1 tentang diagram karakteristik psikologis atlet PON Bengkulu ditinjau dari cabang olahraga individu secara umum.

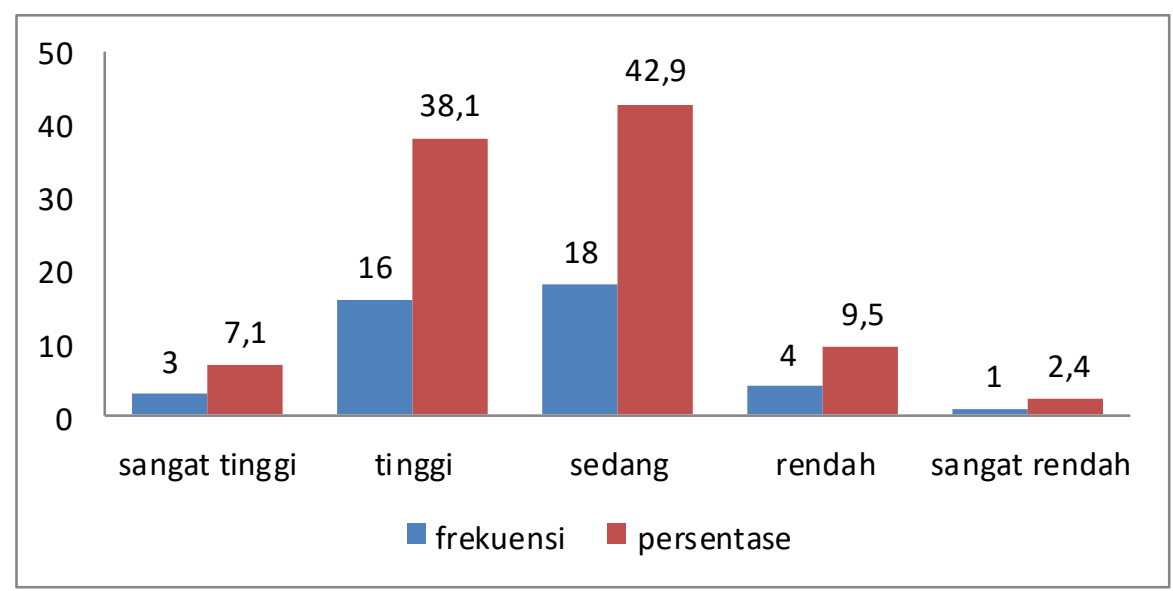

Gambar 1. Diagram Karakteristik Psikologis Atlet PON Bengkulu Ditinjau dari Cabang Olahraga Individu Secara Umum

\section{Uji Normalitas}

Uji normalitas adalah sebuah uji yang dilakukan dengan tujuan untuk menilai sebaran data pada sebuah kelompok data atau variabel, apakah sebaran data tersebut berdistribusi normal ataukah tidak. Uji normalitas menggunakan uji Kolmogorov-Smirnov dengan kriteria sebagai berikut :

1. Jika nilai sig. $<0,05$ maka Ho ditolak. Sehingga data tersebut berasal dari populasi yang berdistribusi tidak normal.

2. Jika nilai sig. $>0,05$ maka Ho diterima. Sehingga data tersebut berasal dari populasi yang berdistrbusi normal. 
Tabel 3. Hasil Uji Normalitas Data Atlet

\begin{tabular}{ll}
\hline & Cabang Olahraga Individu \\
$N$ & 42 \\
Mean & 125,71 \\
Standar Deviasi & 8,931 \\
Nilai Sig. & 0,200 \\
\hline
\end{tabular}

Berdasarkan tabel 3 dapat diketahui bahwa nilai sig. sebesar 0,200 dimana 0,200 $>0,05$ maka Ho diterima sehingga ditinjau dari cabang olahraga individu populasinya berdistribusi normal.

\section{Uji Homogenitas}

Uji homogenitas adalah pengujian sama tidaknya variansi-variansi dua buah distribusi atau lebih. Uji homogenitas dilakukan untuk mengetahui apakah data dalam variabel $\mathrm{X}$ dan $\mathrm{Y}$ bersifat homogen atau tidak. Uji homogenitas digunakan untuk mengetahui apakah data mempunyai varians yang homogen karena uji beda (uji t) mensyaratkan data harus memiliki varians yang homogen. Uji homogenitas varians menggunakan uji levene's dengan kriteria sebagai berikut :

1) Jika nilai sig. $<0,05$ maka Ho ditolak. Sehingga data memiliki varians yang homogen.

2) Jika nilai sig. $>0,05$ maka Ho diterima. Sehingga data memiliki varians yang homogen.

Tabel 4. Hasil Uji Homogenitas Varians Atlet

\begin{tabular}{llll}
\hline Levene Statistic & $d f 1$ & $d f 2$ & Sig. \\
1,362 & 1 & 40 & 0,250 \\
\hline
\end{tabular}

Berdasarkan pada tabel diatas dapat diketahui bahwa nilai sig. sebesar 0,250 dimana 0,250 > 0,05 maka Ho diterima sehingga data tersebut memiliki varians yang homogen.

\section{Pengujian Hipotesis}

Pengujian hipotesis I bertujuan untuk mengetahui apakah ada perbedaan yang signifikan karakteristik psikologis atlet PON Bengkulu ditinjau dari cabang 
olahraga individu antara atlet laki-laki dan atlet perempuan. Untuk menguji hipotesis maka dilakukan uji beda dengan menggunakan uji t yaitu Independent Sample $t$ test. Hipotesis penelitian ini adalah ada perbedaan karakteristik psikologis atlet ditinjau dari cabang olahraga individu antara atlet laki-laki dan atlet perempuan. Kriteria : Jika sig. $<0,05$ maka Ho ditolak. Sehingga terdapat perbedaan yang signifikan antar kelompok yang dibandingkan.

Tabel 5. Hasil Group Statistics

\begin{tabular}{llrrrr}
\hline & & Group Statistics & & \\
& Jenis Kelamin & $\mathrm{N}$ & Mean & $\begin{array}{c}\text { Std. } \\
\text { Deviation }\end{array}$ & Std. Error Mean \\
Karakteristik & Laki-laki & 23 & 128.22 & 7.699 & 1.605 \\
Psikologis & Perempuan & 19 & 122.68 & 9.569 & 2.195 \\
\hline
\end{tabular}

Berdasarkan tabel diatas dapat diketahui bahwa nilai $\mathrm{t}_{\text {hitung }}=2,078$ dengan nilai sig. $=0,044<0,05$ maka Ho ditolak. Jadi dapat disimpulkan bahwa ada perbedaan rata-rata antara karakteristik psikologis atlet laki-laki dan karakteristik psikologis atlet perempuan.

\section{PEMBAHASAN}

1. Karakteristik Psikologis Atlet PON Bengkulu Ditinjau dari Cabang Olahraga Individu

a. Motivasi

Berdasarkan hasil analisis data diketahui bahwa motivasi atlet ditinjau dari cabang olahraga individu dalam kategori tinggi dengan nilai rata-rata sebesar 38,1. Hasil penelitian ini juga didukung oleh hasil penelitian sebelumnya yang menyatakan bahwa motivasi yang tinggi sangat dibutuhkan oleh atlet dan tidak dapat dipisahkan dari atlet untuk menapai kesuksesan (Nopiyanto \& Dimyati, 2018). Untuk menjadi atlet yang sukses maka diperlukan motivasi yang sangat tinggi, bahkan motivasi tidak dapat dipisahkan dari cabang olahraga individu karena untuk mencapai kesuksesan di PON Papua dibutuhkan motivasi yang tinggi.

\section{b. Kepercayaan Diri}

Berdasarkan hasil analisis data diketahui bahwa kepercayaan diri atlet ditinjau dari cabang olahraga individu dalam kategori sedang dengan nilai ratarata sebesar 59,5. Salah satu modal utama dan syarat mutlak untuk mencapai 
prestasi olahraga yang gemilang adalah memiliki percaya diri (Husdarta 2010: 92). Hasil penelitian ini didukung oleh hasil penelitian sebelumnya yang menyatakan bahwa bahwa ada hubungan yang positif antara kepercayaan diri dengan penampilan dalam olahraga. Penelitian menunjukkan bahwa atlet berprestasi ditinjau dari cabang olahraga individu seperti panahan harus mempunyai kepercayaan diri yang baik (Bebetsos, 2015). Selain itu, kepercayaan diri tidak dapat dipisahkan dari cabang olahraga individu karena untuk mencapai kesuksesan di PON Papua dibutuhkan kepercayaan diri yang tinggi. Sebagaimana yang diketahui bahwa atlet elit yang sukses mempunyai tingkat kepercayaan diri yang tinggi (Dongoran et al, 2019).

c. Kontrol Kecemasan

Berdasarkan hasil analisis data diketahui bahwa kontrol kecemasan atlet ditinjau dari cabang olahraga individu dalam kategori tinggi dengan nilai rata-rata sebesar 45,2. Hasil penelitian yang dilakukan oleh Singh, Sunderlal, dan Ranjit (2014) menyatakan bahwa olahraga individu (panahan, bersepeda, tenis meja, gulat, anggar, atletik, angkat besi, judo, tinju dan taekwondo) mempunyai tingkat kecemasan yang lebih tinggi jika dibandingkan dengan olahraga tim (hoki, bola tangan, kabaddi, sepak-takraw dan bola voli). Tingkat kecemasan atlet ditinjau dari cabang olahraga individu lebih tinggi jika dibandingkan dengan atlet pada olahraga tim (Bookani, Sadeghi, Alipour, Zarga dan Aghdam 2015).

Berdasarkan hasil penelitian sebelumnya dapat disimpulkan bahwa tingkat kecemasan ditinjau dari cabang olahraga individu dalam kategori tinggi. Untuk itulah atlet PON Bengkulu ditinjau dari cabang olahraga individu harus mempunyai kontrol kecemasan yang tinggi. Kontrol kecemasan tidak dapat dipisahkan dari cabang olahraga individu karena untuk mencapai kesuksesan di PON Papua dibutuhkan kontrol kecemasan yang tinggi.

\section{d. Persiapan Mental}

Berdasarkan hasil analisis data diketahui bahwa persiapan mental atlet ditinjau dari cabang olahraga individu dalam kategori rendah dengan nilai rerata sebesar 42,9. Hasil penelitian ini menunjukkan bahwa atlet PON Bengkulu telah melakukan persiapan mental yang meliputi aspek kognitif, emosi, perilaku dan 
psikologis. Persiapan mental sama pentingnya dengan persiapan secara fisik dan teknik (Harsono, 2015).

e. Pentingnya Tim

Berdasarkan hasil analisis data diketahui bahwa "pentingnya tim" atlet ditinjau dari cabang olahraga individu dalam kategori sedang dengan nilai ratarata sebesar 50,0. Meskipun cabang olahraga individu dilakukan secara individual namun untuk mencapai kesuksesan dibutuhkan kerjasama antara atlet, pelatih, psikolog olahraga. Atlet PON Bengkulu mempunyai nilai kerjasama yang baik sehingga akan lebih mementingkan kepentingan bersama dibandingkan kepentingan pribadi. Hasil penelitian yang serupa juga menyatakan hal yang sama bahwa untuk mendapatkan prestasi yang baik maka diperlukan langkah yang mendahulukan kepentingan tim dibandingkan dengan kepentingan individu (Nopiyanto, Dimyati, \& Dongoran, 2019).

\section{f. Konsentrasi}

Berdasarkan hasil analisis data diketahui bahwa konsentrasi atlet ditinjau dari cabang olahraga individu dalam kategori tinggi dengan nilai rata-rata sebesar 31,0. Hasil penelitian ini sesuai dengan teori yang menyatakan bahwa konsentrasi merupakan salah satu faktor psikologis yang berpengaruh terhadap penampilan atlet. Konsentrasi sangat penting peranannya dalam olahraga karena jika terganggu maka akan timbul masalah. Masalah yang paling sering timbul akibat terganggunya konsentrasi adalah berkurangnya akurasi lemparan, pukulan, tendangan dan tembakan sehingga tidak mengenai sasaran (Mardhika \& Dimyati, 2015). Dengan adanya konsentrasi maka aktivitas-aktivitas tersebut akan berjalan lancar dan sesuai dengan keinginan. Dan ketika konsentrasi terganggu akurasi lemparan, pukulan dan tembakan akan berkurang sehingga hal yang seharusnya memiliki ketepatan dalam melakukannya menjadi gagal karena minimnya tingkat konsentrasi yang dimiliki oleh seseorang (Komarudin, 2015). Semua cabang olahraga yang diikutsertakan di PON Papua membutuhkan konsentrasi tinggi, jadi tidak mengejutkan jika hasil penelitian ini menunjukkan bahwa atlet PON Bengkulu mempunyai konsentrasi tinggi. 


\section{Perbedaan Karakteristik Psikologis Atlet PON Bengkulu Cabang Olahraga individu Berdasarkan Jenis Kelamin}

Berdasarkan hasil analisis data dapat diketahui bahwa nilai rata-rata atlet laki-laki dari cabang olahraga individu sebesar 7,699 dan atlet perempuan sebesar 9,569 serta $t_{\text {hitung }}=2,078$ dengan nilai sig. sebesar 0,044 $\mathrm{p}<0,05$ maka Ho ditolak. Jadi dapat disimpulkan bahwa ada perbedaan yang signifikan karakteristik psikologis atlet PON Bengkulu ditinjau dari cabang olahraga individu berdasarkan jenis kelamin. Hasil penelitian ini sesuai dengan penelitian sebelumnya yang menyatakan bahwa ada perbedaan yang signifikan karakteristik psikologis atlet laki-laki dan perempuan ditinjau dari cabang olahraga individu. Penelitian yang serupa juga dinyatakan oleh (Nopiyanto \& Alimuddin, 2020) yang menyatakan terdapat perbedaan yang signifikan antara karakteristik psikologis atlet laki-laki dan perempuan. Deanar, Carter, Joyner, Hunter (2015) menemukan bahwa atlet laki-laki mempunyai ketertarikan yang lebih tinggi untuk berkompetisi dan menjadi pemenang sebagai motif untuk berprestasi dalam olahraga sedangkan orientasi tujuan dinyatakan sama antara atlet perempuan dan atlet laki-laki. Namun, berdasarkan penelitian lainnya yang dilakukan oleh (Nopiyanto, Raibowo, \& Ugo, 2021) yang mengkaji tentang karakteristik psikologis atlet pusat pedidikan dan latihan pelajar (PPLP) Provinsi Bengkulu diketahui tidak ada perbedaan yang signifikan antara atlet laki-laki dan perempuan, karena atlet lakilaki dan atlet perempuan di PPLP memiliki tujuan yang sama untuk mendapatkan prestasi terbaiknya, tidak adanya perbedaan karakteristik psikologis juga dikarenakan subjek dalam penelitian ini masih remaja dan berstatus sebagai pelajar.

\section{KESIMPULAN}

Berdasarkan hasil penelitian dan pembahasan yang telah diuraikan maka dapat disimpulkan bahwa karakteristik psikologis atlet PON Bengkulu ditinjau dari cabang olahraga individu sebagian besar berada pada kategori tinggi, terdiri dari aspek motivasi pada kategori tinggi dengan skor 38,1 ; kepercayaan diri pada kategori sedang dengan skor 59,5; kontrol kecemasan pada kategori tinggi dengan skor 45,2; persiapan mental pada kategori rendah dengan skor 42,9; pentingnya tim pada kategori sedang 50,0; dan konsentrasi pada kategori sedang dengan skor 
42,9. Terdapat perbedaan yang signifikan karakteristik psikologis atlet PON Bengkulu ditinjau dari cabang olahraga individu berdasarkan jenis kelamin. Nilai rata-rata atlet laki-laki dari cabang olahraga individu sebesar 128,22 dan atlet perempuan sebesar 122,68

\section{REFERENSI}

Anagnostopoulus, V., Carter. \& Weissbrod. (2015). Pre-Competition Anxiety and Self-Confidence in Collegiate Track and Field Athletes: A Comparison Between African American and Non-Hispanic Caucasian Men and Women. The Sport Journal.

Bookani, A. N., Sadeghi, O., Alipour, K., Zarga, K., \& Aghdam, B. L. (2015). Analyzing effects of anxiety and selfconfidence on athletic performance,". Indian Journal of Fundamental and Applied Life Sciences', Retrived from: http://www. cibtech. org/sp. ed/jls/2015/01/41-JLS-S1-044(6). pdf. Accessed on, 9,

Deaner, R. O., Carter, R. E., Joyner, M. J., Hunter, S. K. (2015). Men are More Likely Than Women to Slow in The Marathon. Medicine and Science in Sports and Exercise, 47, 607-616.

Dongoran, M., Nopiyanto, Y., Saputro, D., \& Nugroho, A. (2019, November). Comparison of Psychological Skills of Pencak Silat and Boxing Athletes (Study on Indonesian Training Camp athletes). In International Conference on Social Science 2019 (ICSS 2019) (pp. 182-186). Atlantis Press.

Effendi, H. (2016). Peranan psikologi olahraga dalam meningkatkan prestasi atlet. NUSANTARA: Jurnal Ilmu Pengetahuan Sosial, 1(1).

Garratt, R. J., Weinberger, C., \& Johnson, N. (2013). The state street mile: Age and gender differences in competition aversion in the field. Economic Inquiry, 51(1), 806-815.

Husdarta, H. J. S. (2010). Psikologi olahraga. Bandung: Alfabeta.

Jahja, Y. (2011). Psikologi perkembangan. Kencana.

Maksum, A. (2011). Psikologi Olahraga Teori dan Aplikasi. Surabaya: Universitas Negeri Surabaya.

Mardhika, R., \& Dimyati, D. (2015). Pengaruh Latihan Mental dan Keyakinan Diri Terhadap Keberhasilan Tendangan Penalti Pemain Sepak Bola. Jurnal Keolahragaan, 3(1), 106-116.

McNamara, A., Button, A., \& Collins, D. (2010). The role of psychological characteristics in facilitating the pathway to elite performance. The Sport Psychologist, 24, 52-73. 
Nopiyanto, Y. E., \& Alimuddin, A. (2020). Perbedaan Karakteristik Mental Atlet Sea Games di Lihat dari Sisi Gender. Sporta Saintika, 5(1), 72-80.

Nopiyanto, Y. E., \& Dimyati, D. (2018). Karakteristik psikologis atlet Sea Games Indonesia ditinjau dari jenis cabang olahraga dan jenis kelamin. Jurnal Keolahragaan, 6(1), 69-76.

Nopiyanto, Y. E., Dimyati, D., \& Dongoran, F. (2019). Karakteristik Psikologis Atlet Sea Games Indonesia Ditinjau Dari Cabang Olahraga Tim. Sporta Saintika, 4(2), 27-46.

Nopiyanto, Y. E., Raibowo, S., \& Prabowo, G. U. (2021). Psychological Characteristics of Athletes at Student's Education and Training Center in Bengkulu. Journal Sport Area, 48-57. 